\title{
CHILDREN IN POVERTY: TRENDS, CONSEQUENCES, AND POLICY OPTIONS
}

By Kristin Anderson Moore, Ph.D., Zakia Redd, M.P.P., ${ }^{1}$ Mary Burkhauser, M.A., Kassim Mbwana, M.P.P, and Ashleigh Collins, M.A.

April 2009

\section{OVERVIEW}

The number of U.S. children living in poverty increased in 2007-continuing an upward trend dating back to 2000: In 2007, 13.3 million children were living in poverty, up from 11.6 million children in $2000 .^{2}$ The percentage of children living in families with incomes below the poverty line has increased from 16.2 percent in 2000 to 18.0 percent in 2007. ${ }^{3}$ Thus, a large number of children-nearly one in five-are poor. ${ }^{a}$

Child poverty merits attention because a substantial body of research links poverty with lower levels of child well-being. For a variety of reasons, when compared with children from more affluent families, poor children are more likely to have low academic achievement, to drop out of school, and to have health, behavioral, and emotional problems. These linkages are particularly strong for children whose families experience deep poverty, who are poor during early childhood, and who are trapped in poverty for a long time.

This Research Brief draws on Census data for 2007 to present a statistical portrait of children in poverty in the United States, ${ }^{4}$ updating similar briefs Child Trends produced in 1999 and 2002. The brief highlights research on the consequences of poverty for children and suggests program and policy approaches that hold promise for decreasing poverty among low-income children and their families.

\section{TRENDS}

The overall child poverty rate rose significantly.

- For children younger than 18, the poverty rate increased from 17.4 percent in 2006 to 18 percent in 2007, the highest rate since 1998. This 18 percent translates into 13.3 million children living in poverty in the United States in $2007,,^{5}$ an increase of 497,000 children between 2006 and $2007 .{ }^{6}$

\section{The percentage of children living in deep poverty had been declining at the turn of the century but is now on the rise.}

- In 2007, 8 percent of children lived in deep or extreme poverty (below 50 percent of the poverty line). ${ }^{7}$ The percentage of children living in extreme poverty was 9 percent in 1995 and had decreased to 7 percent by 2000 . Since 2003 , it has been 8 percent. $^{8}$

- Analyses suggest that children experiencing extreme poverty may be even worse off than their counterparts were in the mid-1990s because their families have become less likely to use the social programs for which they are eligible (such as food stamps and Medicaid). ${ }^{9}$

\footnotetext{
${ }^{a}$ This brief reports on the U.S. official poverty line, which is the measure used in most research studies. Considerable discussion focuses on an improved measure of poverty, recommended a decade ago by the National Research Council. ${ }^{10}$

${ }^{b}$ The 2007 Health and Human Services poverty guidelines list the poverty level at an annual income of $\$ 13,690$ for a two-person household, $\$ 17,170$ for a three-person household, and $\$ 34,570$ for an eight-person household. The poverty line is drawn at slightly higher income levels for residents of Alaska and Hawaii.
} 
Racial and ethnic disparities persist.

- Black and Hispanic children were more than twice as likely to live in poverty in 2007 as non-Hispanic white and Asian children.

- 34.5 percent of black children and 28.6 percent of Hispanic children lived in poverty in 2007, compared with 10.1 percent of non-Hispanic white children and 12.5 percent of Asian children. ${ }^{11}$

Family structure continues to be strongly related to whether or not children are poor.

- In 2007, children living in households headed by single mothers were more than five times as likely as children living in households headed by married parents to be living in poverty- 42.9 percent compared with 8.5 percent. $^{12}$ (See Figure 1.)

\section{Figure 1}

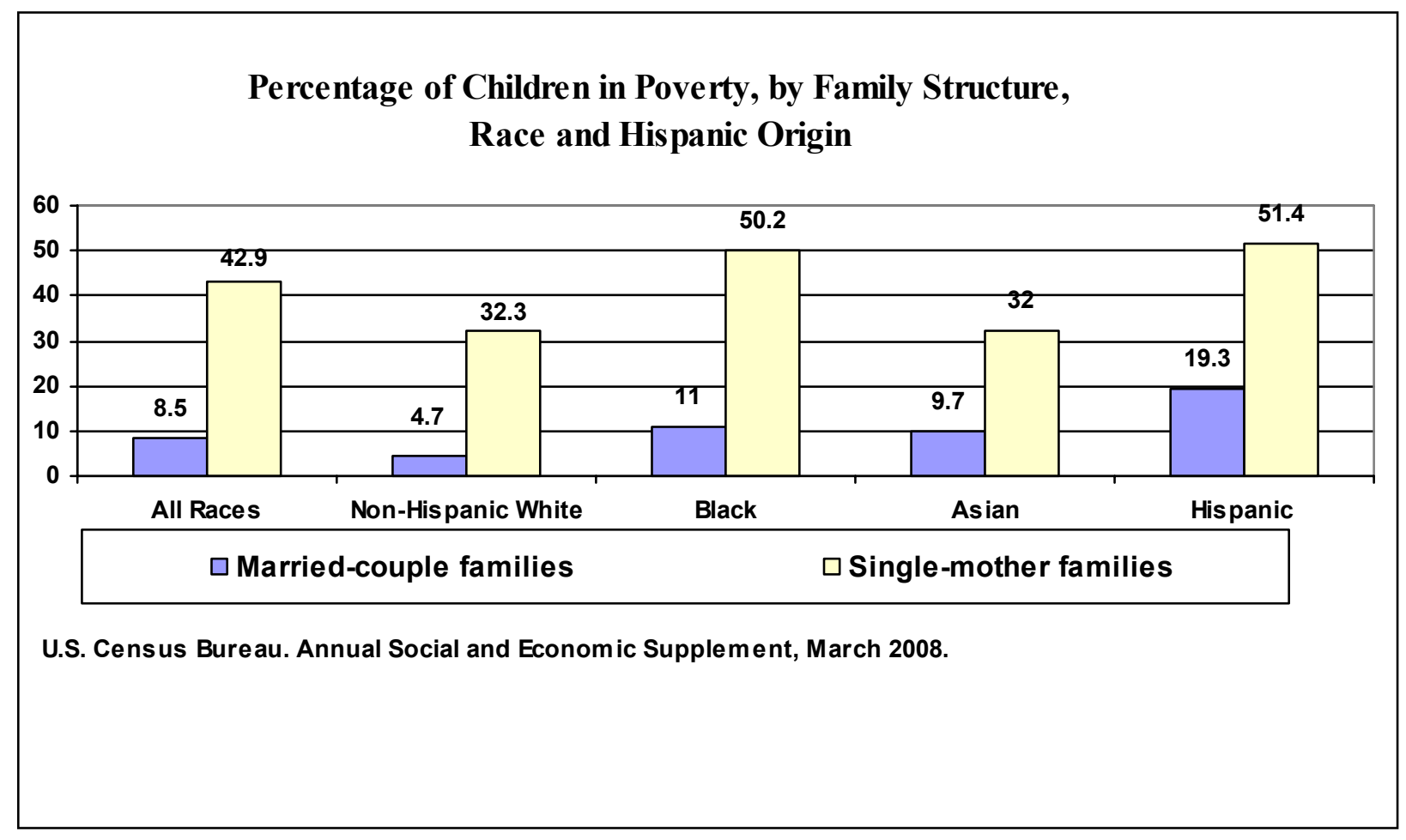

In all race/ethnicity groups, children in single-parent families are much more likely to be poor than children living in households headed by married parents.

- For non-Hispanic white children, the poverty rate in 2007 was 32.3 percent for children in singlemother households compared with 4.7 percent for children in married households.

- Similarly for black children, the poverty rate was 50.2 percent compared with 11 percent.

- For Hispanic children, the poverty rate was 51.4 percent compared with 19.3 percent.

- For Asian children, the poverty rate was 32 percent compared with 9.7 percent.

Having immigrant parents is also associated with a greater likelihood of being poor.

- Analyses by the National Center for Children in Poverty compared the relative proportions of children with immigrant and native-born parents who were in poverty in 2005. In all of the six states examined, poverty rates were higher for children with immigrant parents. ${ }^{13}$ 
Children are almost twice as likely to be poor as older adults.

- In 2007, the poverty rate was:

- 9.7 percent for people 65 and older, compared with

- 18 percent for children younger than $18 .^{14}$ (See Figure 2.)

- In contrast, five decades ago, older Americans were more likely to be poor than children. For example, in 1959:

- More than 35 percent of Americans 65 and older were living in poverty, while

- Less than 30 percent of children under 18 were living in poverty.

- In the 1970 s, the percentage of children living in poverty was on the rise, while older Americans experienced a significant drop in poverty. This drop reflects, at least in part, a societal commitment to improve the lot of the nation's elders by increasing the generosity of such programs such as Social Security, which has lifted millions of older Americans out of poverty. ${ }^{15}$

- Between 2000 and 2007, although the poverty rate remained largely unchanged for people 65 and older, it increased somewhat for adults between the ages of 18 to 64 , and significantly for those under age 18 .

\section{Figure 2}

Poverty Rates by Age: 1959 to 2007

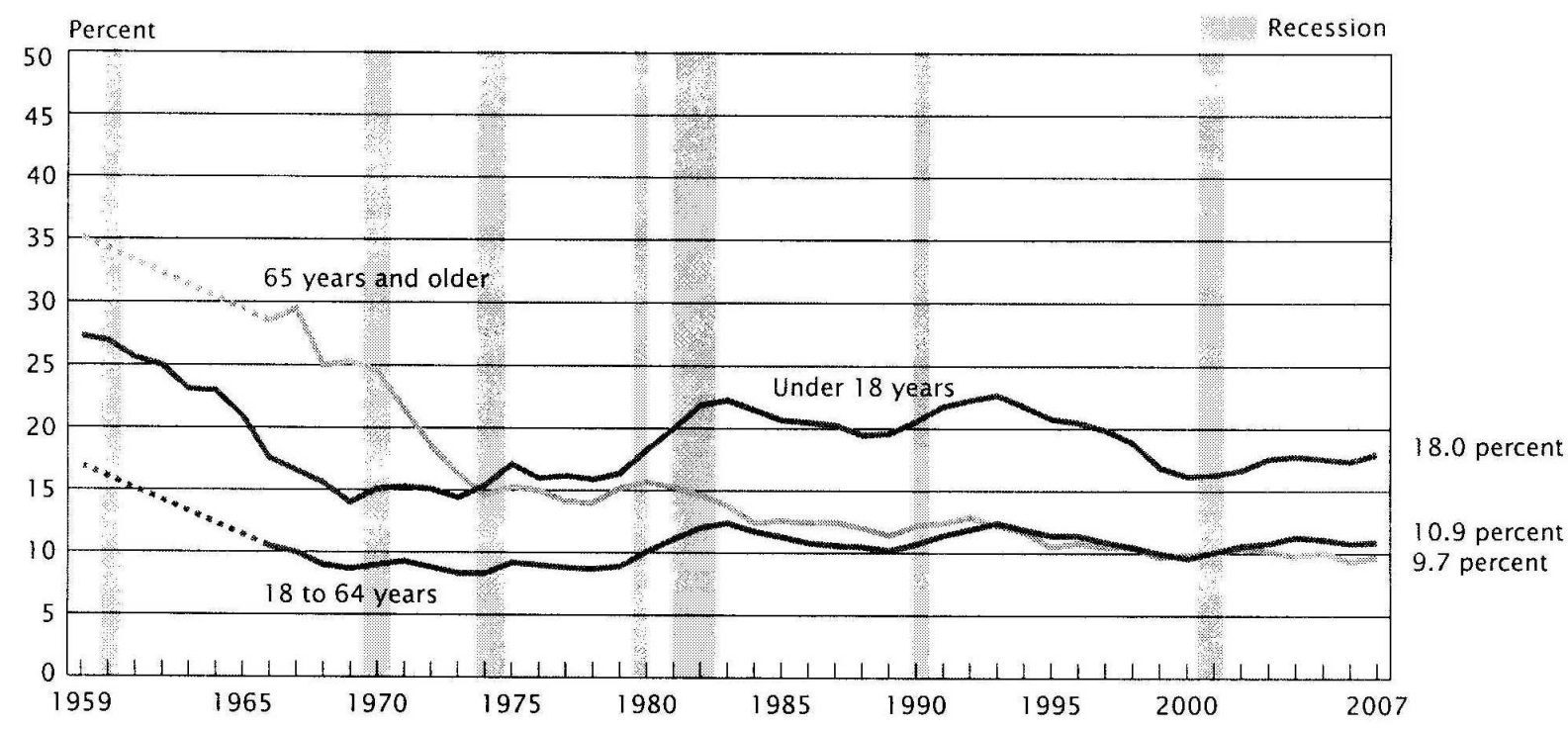

Note: Data for people aged 18 to 64 and 65 and older are not available from 1960 to 1965 . For information on recessions, see Appendix A. Source: U.S. Census Bureau, Current Population Survey, 1960 to 2008 Annual Social and Economic Supplements.

The child poverty rate in the United States surpasses that of many other industrialized nations.

- Analyses comparing child poverty rates across nine wealthy nations using the U.S. Poverty Standard indicate that the proportion of children below 125 percent of the poverty line at the start of the decade was higher in the U.S. than in almost any other industrialized country, with the exception of the United Kingdom: ${ }^{16}$

- 4.6 percent in Finland;

- 5.8 percent in Austria;

- 7.2 percent in Belgium; 
- 9 percent in Canada;

- 9.1 percent in Germany;

- 10.4 percent in the Netherlands;

- 12.4 percent in the United States; and

- 17.5 percent in the United Kingdom.

- In 1999, the United Kingdom began a 20 -year mission to end child poverty, ${ }^{17}$ and has made some progress: In 2006, then Prime Minister Tony Blair reported a 23 percent decrease in child poverty between 1998 and 2004. ${ }^{18}$

\section{Consequences of CHILd Poverty}

Research finds that children who are raised in poverty are at increased risk of a wide range of negative outcomes that are identified at birth and can extend into adulthood. ${ }^{19}$ Negative outcomes are particularly associated with deep and long-term poverty and with poverty in early childhood. We provide an overview of these findings here.

Educational and cognitive outcomes. A review of ten studies on the effects of poverty on children concluded that poverty has large and consistent associations with negative academic outcomes. ${ }^{20}$ Studies have found consistently large negative associations between poverty during early childhood and academic outcomes, ${ }^{21,22}$ while studies measuring poverty during adolescence have been less consistent. ${ }^{22}$ For example, one study found that recent poverty may be more strongly associated with lower achievement scores than early poverty for adolescents. ${ }^{24}$ Poverty has also been linked to a greater likelihood of adolescents dropping out of high school. ${ }^{25}$ In addition, a study of changes in family incomes found that children "whose families go from being above poverty to either being poor or on welfare" 26 have lower reading scores than children whose families were never poor.

How does poverty influence cognitive and educational outcomes? Researchers suggest that the pathways are often indirect. Poor children are more likely than their more affluent peers to be raised by parents who have completed fewer years of education, and to grow up in households that are less cognitively stimulating, ${ }^{27}$ which can negatively affect children's cognitive and academic attainment. ${ }^{28}$ They are also more likely to attend schools that lack the resources and rigor of schools in more prosperous neighborhoods. Moreover, emerging research is finding that socioeconomic status affects neuro-cognitive brain functioning. ${ }^{29}$ One recent study finds that chronic stress due to family poverty undermines children's working memory. ${ }^{30}$ Poorer health and social behavior due to poverty also undermine educational achievement.

Social and emotional development. Poverty is also related to children's social and emotional development. Children in poverty have a greater risk of displaying behavior and emotional problems, such as disobedience, impulsiveness, and difficulty getting along with peers. ${ }^{31,32,33,34,35,36,37,38}$ Children in poverty display fewer positive behaviors (such as compliance) than their non-impoverished peers. ${ }^{39,40}$ Family poverty is also associated with a higher risk for teen childbearing, less positive peer relations, and lower selfesteem compared with children who have never experienced poverty. ${ }^{41,42,43,44,45}$ One study found that longterm poverty is associated with children's inner feelings of anxiety, unhappiness, and dependence, while current poverty is associated with acting out, disobedience and aggression. ${ }^{46}$

Why might poverty influence children's social, emotional, and behavioral outcomes? One explanation is that poor children are more likely to be raised by single parents and (perhaps related to this) to live in households where there is less parental supervision and more parental distress. Research finds that poor 
children are more likely to experience frequent moves and changes in family structure than more affluent children. ${ }^{48,49,50}$ In turn, children with such turbulent lives are more likely to have negative social and emotional outcomes than children whose lives are relatively stable. ${ }^{51}$

Another explanation for the influence of poverty on children's social, emotional, and behavioral outcomes is that children in low-income families and neighborhoods may be less likely than children who grow up in more economically comfortable circumstances to be exposed to positive social norms in their lives and neighborhoods. ${ }^{52,53}$ For example, homicide rates are highest in areas of extreme poverty, and children exposed to such violence are at greater risk of psychosocial difficulties, such as internalizing behaviors (such as depression) and acting out behaviors (such as disobedience). ${ }^{54,55,56}$ Researchers also suggest that increased "acting out" among children in poverty might reflect parents' lower levels of emotional responsiveness to their children, more frequent use of physical punishment, and lower quality home environment. $^{57}$

Overall, poor children may be less likely to have the kinds of buffers in their lives that can protect them from negative influences. This may be because poverty appears to inhibit families' ability to achieve social control and, consequently, increases the likelihood of adolescent delinquency. ${ }^{58}$ These difficulties during childhood can translate into difficulties during adulthood.

Economic outcomes as adults. Studies find that those who experienced persistent poverty as children are much more likely to be poor as adults than those who were not poor during childhood. ${ }^{59}$ For example, adolescents who have experienced poverty are more likely to earn low wages than their peers who grew up in less dire circumstances. ${ }^{60}$ While upward mobility among adults who grew up poor is not uncommon, adults who experienced persistent childhood poverty are more likely to fall below the poverty line at least once later in life. However, upward mobility is not uniform across all races of children; 33 percent of African American children who were poor during childhood remained poor at ages 25-27, compared with 7 percent of poor white children. ${ }^{61}$

In the long run, childhood poverty poses economic costs to the United States through reduced productivity and output, the cost of crime, and increased health expenditures. Children who grow up in poverty are more likely to have low productivity and low earnings relative to children who did not grow up in poverty. It has been estimated that the reduced productivity lowers the gross domestic product by 1.3 percent annually. ${ }^{62}$

Health outcomes. National data indicate that poor health outcomes are more prevalent among poor children from birth onward. For example, poor children are more likely to be of low birth weight and to die in the first month of life than children who are not born into poverty. ${ }^{63}$ Infants living in poor households are more likely to experience food insecurity. (Food insecurity includes not having enough to eat, having a diet that is inadequate, and having parents who worry about being able to afford the amount and type of food that a household needs. ${ }^{64}$ ) In addition, children who are poor are at greater risk of experiencing accidents and injuries than children who are not living in poverty. ${ }^{65}$

Research finds that experiencing poverty during the first three years of life is related to substandard nutritional status and poor motor skills. ${ }^{66}$ Childhood poverty is also related to "age-normed growth stunting" (low height-for-age) and "wasting" (low weight-for-age), common indicators of poor nutritional status. ${ }^{67}$ At the other extreme, poverty is also associated with obesity among children. ${ }^{68}$ As they get older, 
poor children are more likely than other children to have chronic health problems such as asthma and anemia. ${ }^{69}$ Low-income children and adolescents are also more likely than higher income youth to have a physical impairment that restricts their activities. ${ }^{70}$ Adolescents living in poverty are more likely than their higher income peers to get involved in risky and health-compromising behaviors, such as smoking ${ }^{71}$ or engaging in early sexual activity. ${ }^{72}$ Health problems associated with poverty during early childhood become risk factors themselves for developmental problems in later life, including problems in the achievement, cognitive, language, social-emotional, and physical domains. ${ }^{73}$

In particular, health and safety outcomes are worse for children who experience long-term poverty. For example, differences in height between poor and non-poor children are greater when using a long-term measure of poverty, even controlling for family and child characteristics associated with poverty. ${ }^{74}$

Researchers note that there are many possible pathways by which poverty can affect health. For instance, poor children are disproportionately exposed to risk factors, including environmental toxins, inadequate nutrition, maternal depression, parental substance abuse, trauma and abuse, violent crime, divorce, and low quality child care. ${ }^{75,76,77,78,79,80,81}$ Poor families are more likely to live in substandard housing ${ }^{82}$ that may have lead paint and other health hazards. ${ }^{83}$ They are also more likely to live in disadvantaged neighborhoods that are not safe, that provide fewer positive models of people who exhibit healthy behaviors,$^{84}$ and that have fewer stores that sell healthy foods. Also, living in households that sometimes don't have enough nutritious food may explain why some children's growth is stunted. ${ }^{85}$

An important caveat. When parents are poor, they are more likely to have additional disadvantages (such as a low level of education or mental health problem) that can have a negative effect on their children's well-being. ${ }^{86}$ These other important contributing factors can also undermine children's development. ${ }^{87}$ Researchers have used varied strategies to account for measured (e.g., parent education) and unmeasured (e.g., parent motivation) factors associated with poverty. ${ }^{88}$ In these analyses, the effects of poverty, per se, are greatly reduced. More research is needed to better understand how poverty affects children's wellbeing. However, research studies conducted thus far indicate that reducing poverty can improve the lives of children.

\section{Implications For Public Policy}

There are no easy solutions to the formidable task of reducing child poverty or alleviating its consequences. Research does suggest, however, possible options for policymakers to consider as they approach this task. ${ }^{89}$ These include:

- Build on successful welfare-to-work initiatives. Experimental studies of demonstration welfare-to-work programs indicate that when these programs included financial incentives for finding, keeping, and holding a job, both employment and family income improved. ${ }^{90}$ These results suggest that wage supplements, earned income credits, and other means of raising the income of welfare recipients and other low-income wage earners can be effective investments for parents, children, and the larger society. Efforts to build supports at the community level, such as job creation and transportation, may augment the effectiveness of programs.

- Maintain financial work supports and reduce the marriage penalty within the Earned Income Tax Credit (EITC). The number of poor children who have working parents has increased substantially since expansion of the EITC and passage of the federal welfare reform law. ${ }^{91,92}$ Research suggests that 
programs that help make work pay for parents help their children as well. ${ }^{93}$ The EITC is particularly noteworthy in this regard. Analyses have shown that in 2003, an estimated 2.4 million children were lifted out of poverty by the EITC. ${ }^{44}$ The "marriage penalty" in the EITC refers to the usual reduction in this benefit if a working parent who qualifies for the full EITC marries another working adult. ${ }^{95}$ Increasing the Child Tax Credit and making it refundable is another potential approach. ${ }^{96}$

- Support efforts to strengthen marriages and to decrease births to teens and unmarried women. Data presented earlier in this brief indicate that children born to unmarried parents and living in singleparent households are more likely to be poor than those being raised in two-parent households. Studies identifying effective approaches to support healthy marriage and prevent teen childbearing can contribute to this discussion.

- Redouble efforts to promote child support enforcement, job training, and father involvement. Analyses of increases in child support enforcement strongly suggest that it has played a role in decreasing child poverty. ${ }^{98}$ One study estimated that, in 1996, child support lifted about a half million children out of poverty. ${ }^{99}$ The same study also estimated that, for children with non-resident parents who received child support, on average, these payments make up more than one-quarter of their family's income. For poor children who don't receive welfare, the study found that child support payments represented more than one-third of their family's income. ${ }^{100}$

When families receive welfare, many states have policies requiring that some or all of the child support payments by non-resident parents go to the government. A child support demonstration program in Wisconsin that allowed all child support to go directly to the child's family resulted in a modest increase in the percentage of fathers who supported their children financially and a small increase in the average amount of child support that these families received, compared with a group of welfare households that received a reduced amount. ${ }^{101}$

Some evidence from non-experimental research studies also suggests that nonresident fathers who provide financial support are more likely to be involved in their children's lives. ${ }^{102}$ A note of caution is important here: Research finds that many non-resident fathers do not provide financial support to their children not necessarily because they are "deadbeat" dads, but because they are not able to do so financially. ${ }^{103}$ Job training coupled with other services for non-resident fathers may help to improve their employment prospects and thus their ability to pay child support. ${ }^{104,105}$ Such services are needed by incarcerated fathers in particular.

- Continue child care subsidies and assess whether more funding is needed. Child care constitutes a major cost for working poor families. For example, one study noted that in 2003, 23 percent of lowincome, two-parent families, and 40 percent of working poor families headed by single mothers, who paid for child care spent more than half their cash income on child care expenses. ${ }^{106}$

- Inform low-income parents about food and health care assistance. Low-income children are more likely to not have enough to eat at times ${ }^{107}$ and are less likely to be covered by health insurance. ${ }^{108}$ Additionally, research indicates that many low-income families do not use supportive programs for which they are eligible. ${ }^{109}$ Increasing efforts to make sure poor parents know about their eligibility for services, such as food stamps and Medicaid - and how they can apply for them - may help them to increase the income they have available to cover other needs and expenses. Assistance with housing 
represents another increasingly important concern. Taking advantage of available services may also buffer them and their children from some of the increased risks associated with poverty.

Another perspective on addressing poverty focuses on the "demand" side. With significant job losses being experienced at present, economic stimulus efforts at the national, state, and local level, can reduce unemployment, and provide adequate benefits in case of unemployment, and thus reduce poverty.

\section{CONCLUSION}

The information presented in this Research Brief highlights the increase in child poverty in the United States through 2007. Nearly one out of five children was living in poverty in 2007, and this percentage has been increasing since 2000, resulting in 13.3 million poor children in 2007 . Thus, child poverty was a significant and growing social problem-even prior to the current economic recession. Research suggests that poverty is one of the factors that negatively affects children's development, especially deep, long-term poverty. Research also suggests that a combination of parental effort and social programs - correctly designed and implemented - can improve the lives of poor children and their families. Both the statistical data and the research findings cited in this brief underscore the need to resume efforts to reduce the child poverty rate, even as other issues command the nation's attention. 


\section{REFERENCES}

${ }^{1}$ Zakia Redd contributed to this brief while employed at Child Trends as a Senior Research Analyst in 2002.

${ }^{2}$ That is, their family's income fell below the official poverty threshold, which varies depending upon the number of adults and children in the family. The poverty threshold for a family of four with two children in 2001 was $\$ 17,960$. The official definition of poverty is based on pretax money income; it excludes capital gains, the earned income tax credit, and noncash benefits, such as Medicaid, food stamps, and child care or housing subsidies. The percentage of children in poverty is sensitive to the definition of income. For instance, Census analyses show that if six experimental poverty measures that define family income differently were in place, each of them would yield poverty rates for children that were slightly lower (14.5-15.8 percent) in 2001 than the official rate (at 16.3 percent). Each year, the official poverty threshold is updated for inflation using the Consumer Price Index (CPI-U). For the federal poverty thresholds for families of different configurations or for past years, please visit the Web site of the U.S. Census Bureau at http://www.census.gov/hhes/poverty/threshld.html.

${ }^{3}$ Ibid.

${ }^{4}$ Much of this information is drawn from the Child Trends DataBank. The DataBank is a continuously updated online resource providing information on more than $70 \mathrm{key}$ indicators of child and youth well-being. However, some estimates differ slightly from those presented in the DataBank because most of the estimates in this Research Brief are based on all children under the age of 18, whereas the DataBank estimates are largely for children related to head of household.

${ }^{5}$ U.S. Census Bureau, 2008.

${ }^{6}$ These analyses are based on the official U.S. poverty rate. A discussion of ways to strengthen the measurement of poverty, as well as ways to improve data on children more generally, is provided in Brown, B. and Moore, K.A. (2009). What Gets Measured Gets Done: High Priority Opportunities to Improve Our Nation's Capacity to Monitor Child and Youth Well-Being. Washington, DC: Child Trends.

${ }^{7}$ Federal Interagency Forum on Child and Family Statistics. America's Children: Key National Indicators of Well-Being, 2007. Federal Interagency Forum on Child and Family Statistics, Washington, DC: U.S. Government Printing Office.

${ }^{8}$ Ibid.

${ }^{9}$ Lerman, R., \& Wiseman, M. (2002). Restructuring food stamps for working families. Washington, DC: The Urban Institute; Zedlewski, S.R., Giannarelli, L., Morton, J. \& Wheaton, L. (2002). Extreme poverty rising, existing government programs could do more. Washington, DC: The Urban Institute; Zedlewski, S.R. (2004). Recent Trends in Food Stamp Participation: Have New Policies Made a Difference? Washington, DC: The Urban Institute; Dorn, S. \& Kenney, G.M. (2006). Automatically Enrolling Eligible Children and Families into Medicaid and SCHIP: Opportunities, Obstacles, and Options for Federal Policymakers. New York, NY: The Commonwealth Fund.

${ }^{10}$ Citro, C., \& Michael, R. (1995). Measuring Poverty: A New Approach. Washington, DC: The National Academies Press.

${ }^{11}$ U.S. Census Bureau. Annual Social and Economic Supplement. Retrieved on September 4, 2008, from http://pubdb3.census.gov/ macro/032008/pov/toc.htm.

${ }^{12}$ Ibid.

${ }^{13}$ The percentage of poor children with immigrant parents is as follows: In California, 26\% (compared to 14\% among children with nativeborn parents); in Florida; $20 \%$ (compared to 18\%); in Illinois, 20\% (compared to 17\%); in New Jersey, 14\% (compared to 8\%); in New York, 25\% (compared to 19\%); and, in Texas, 40\% (compared to 18\%). From the National Center for Children in Poverty. 2006. Who Are America's Poor Children? The Official Story.

${ }^{14}$ U.S. Census Bureau, 2008.

${ }^{15}$ Porter, K.H., Larin, K., \& Primus, W. (1999). Social Security and poverty among the elderly. Washington, DC: Center on Budget and Policy Priorities; Bianchi, S. M. (1999). Feminization and juvenilization of poverty: Trends, relative risks, causes, and consequences. Annual Review of Sociology, 25, 307-333; Sawhill, I. (2008). Paying for Investments in Children. Washington, DC: First Focus.

${ }^{16}$ Timothy Smeeding, 2006. Poor People in Rich Nations: The United States in a Comparative Perspective.

${ }^{17}$ Blair, Tony. 1999. "Beveridge Revisited: A Welfare State for the $21{ }^{\text {st }}$ Century." In Ending Child Poverty: Popular Welfare for the $21^{\text {st }}$ Century, edited by Robert Walker. Bristol, U.K.: Policy Press.

${ }^{18}$ Blair, T. (2006). "Our Nation's Future: Social Exclusion." Retrieved September 25, 2008, from http://www.number10.gov.uk/Page10037.

${ }^{19}$ Gershoff, E.T., Aber, L. and Raver, C. (2003). Child Poverty in the United States: An Evidence-Based Conceptual Framework for Programs and Policies. In Jacobs, F., Wertleib, D. and Lerner, R. (Eds.) Handbook of Applied Developmental Science, Vol. 2 (pp.81-135). Thousand Oaks, CA: Sage Publications.

${ }^{20}$ Brooks-Gunn \& Duncan, 1997; Duncan, G. J. \& Brooks-Gunn, J. (1997). Income effects across the life span: Integration and interpretation. In G. J. Duncan \& J. Brooks-Gunn (Eds.), Consequences of growing up poor (pp. 596-610). New York: Russell Sage Foundation.

${ }^{21}$ Ibid.

${ }^{22}$ Brooks-Gunn, J., \& Duncan, G.J., (1997). The effects of poverty on children. The Future of Children: Children and Poverty, 7, 55-71. Duncan, G.J., Yeung, J. W., Brooks-Gunn, J., Smith, J.R. (1998). Guo, G. (1998). The timing of the influences of cumulative poverty on children's cognitive ability and achievement. Social Forces, 77, 257-287. Haveman, R.H., \& Wolfe, B.S.(1994). Succeeding generations: On the effects of investment in children. New York, NY: Russell Sage Foundation.

${ }^{23}$ Smith, J. R., Brooks-Gunn, J., \& Klebanov, P.K., (1997). Consequences of living in poverty for young children's cognitive and verbal ability and early school achievement. In G. J. Duncan \& J. Brooks-Gunn (Eds.), Consequences of growing up poor. New York: Russell Sage Foundation. 598.

${ }^{24}$ Guo, G. (1998). The timing of influences of cumulative poverty on children's cognitive ability and achievement. Social Forces, 77(1), 257287.

${ }^{25}$ Teachman, J. D., Paasch, K. M., Day, R. D., \& Carver, K. P. (1997). Poverty during adolescence and subsequent educational attainment. In G. J. Duncan \& J. Brooks-Gunn (Eds.), Consequences of growing up poor (pp. 382-418). New York: Russell Sage Foundation; Haveman, Wolfe, \& Wilson, 1997. 
${ }^{26}$ Moore, K.A., Glei, D.A., Driscoll, A.K., Zaslow, M.J., Redd, Z. (2002). Poverty and Welfare Patterns: Implications for Children. The Journal of Social Policy, 31(2), 207-227.

${ }^{267}$ McLoyd, 1998; Yeung, W.J., Linver, M.R., \& Brooks-Gunn, J. (in press). How money matters for young children's development: Investment and family process. Child Development; Guo, G., \& Harris, K. M. (2000). The mechanisms mediating the effects of poverty on intellectual development. Demography, 37(4), 431-447.

${ }^{28}$ Haveman, R., \& Wolfe, B. (1995). The determinants of children's attainments: A review of methods and findings. Journal of Economic Literature, 32, 1829-1878.

${ }^{29}$ Kishiyama, M.M., Boyce, W.T., Jimenez, A.M., Perry, L.M., \& Knight, R.T. (2009). Socioeconomic Disparities Affect Prefrontal Function in Children. Journal of Cognitive Neuroscience X:Y, 1-10

${ }^{30}$ Gary W. Evans, as cited in "Research Links Poor Kids' Stress, Brain Impairment.” The Washington Post (2009, April 6).

${ }^{31}$ Conger, K. J., Rueter, M. A., Conger, R. D. (2000). The role of economic pressure in the lives of parents and their adolescents: The family stress model. In L. J. Crockett \& R. K. Silbereisen (Eds.), Negotiating adolescence in times of social change (pp. 201-223). New York, NY: Cambridge University Press.

${ }^{32}$ Conger, R. D., Wallace, L. E., Sun, Y., Simons, R. L., McLoyd, V. C., \& Brody, G. H. (2002). Economic pressure in African American families: A replication and extension of the family stress model. Developmental Psychology, 38, 179-193.

${ }^{33}$ Elder, G., Van Nguyen, T., Caspi, A. (1985). Linking family hardship to children's lives. Child Development, 56, $361-375$.

${ }^{34}$ Linver, M. R., Brooks-Gunn, J., \& Kohen, D. E. (2002). Family processes as pathways from income to young children's development. Developmental Psychology, 38, 719-734.

${ }^{35}$ Yeung, W. J., Linver, M. R., \& Brooks-Gunn, J. (2002). How money matters for young children's development: Parental investment and family processes. Child Development, 73, 1861-1879.

${ }^{36}$ Hanson, T., McLanahan, S., \& Thomson, E. (1997). Economic resources, parental practices, and children's well-being. In G. Duncan \& J. Brooks-Gunn (Eds.) The consequences of growing up poor (pp. 541-595). New York, NY: Russell Sage Foundation.

${ }^{37}$ Simons, R., Whitbeck, L., Melby, J., \& Wu, C. (1994). Economic pressure and harsh parenting. In R.D. Conger \& G.H. Elder, Jr. (eds.). Families in troubled times: adapting to change in rural America (pp. 207-222). New York, NY: Aldine de Gruyter.

${ }^{38}$ Takeuchi, D., Williams, D., \& Adair, R. (1991). Economic stress in the family and children's emotional and behavior problems. Journal of Marriage and the Family, 53, 1031-1041.

${ }^{39}$ Dearing, E., Taylor, B. A., \& McCartney, K. (2004). Implications of family income dynamics for women's depressive symptoms during the first three years after childbirth. American Journal of Public Health, 94, 1372-1377.

${ }^{40}$ Taylor, B. A., Dearing, E., \& McCartney, K. (2004). Incomes and outcomes in early childhood. Journal of Human Resources, $39,980-1007$.

${ }^{41}$ Bolder, K., Patterson, C., Thompson, W., and Kupersmidt, J. (1995). Psychosocial adjustment among children experiencing persistent and intermittent family economic hardship. Child Development, 66, 1107-1129.

${ }^{42}$ Wadsworth, M. \& Compas, B. (2002) Coping with family conflict and economic strain: the adolescent perspective. Journal of Research on Adolescence, 12(2), 243-274.

${ }^{43}$ Conger, R., Conger, K., and Matthews, L. (1999). Pathways of economic influence on adolescent adjustment. American Journal of Community Psychology,27(4), 519-41.

${ }^{44}$ Weinger, S. (1998). Poor children "know their place": perceptions of poverty, class, and public messages. Journal of Sociology and Social Welfare, 25, 100-118.

${ }^{45}$ McLeod, J.D. \& Shanahan, M.J. (1993). Poverty, parenting, and children's mental health. American Sociological Review, 58, $351-366$.

${ }^{46}$ Moore, K., Glei, D., Driscoll, A., Zaslow, M, \& Redd, Z. (2002). Poverty and welfare patterns: Implications for children. Journal of Social Policy, 31(2), 207-227.

${ }^{47}$ McLoyd, V.C., \& Wilson, L. (1991). The strain of living poor: Parenting, social support, and child mental health. In A. Huston (Ed.), Children and poverty: Child development and public policy (pp. 105-135). New York: Cambridge University Press; U.S. Department of Housing and Urban Development. (2000). Rental housing assistance-The worsening crisis. Washington, DC: U.S. Department of Housing and Urban Development.

${ }^{48}$ Moore, K., Vandivere, S., \& Ehrle, J. (2000). Turbulence and child well-being. Assessing the New Federalism Report B-16. Washington, DC: Child Trends and The Urban Institute. Available online: http://www.urban.org/UploadedPDF/anf b16.pdf..

${ }^{49}$ Moore, K., Vandivere, S., \& Redd, Z. (2006). A Sociodemographic Risk Index. Social Indicators Research (2006) 75: 48-841.

${ }^{50}$ Pagani, L. S., Boulerice, B., \& Tremblay, R. E. (1997). The influence of poverty upon children's classroom placement and behavior problems during elementary school: A change model approach. In G. J. Duncan \& J. Brooks-Gunn (Eds.), Consequences of growing up poor (pp. 311-339). New York: Russell Sage Foundation.

${ }^{51}$ Moore \& Vandivere, 2001; Moore, Vandivere, \& Redd, forthcoming; Pagani, Boulerice, \& Tremblay, 1997.

${ }^{52}$ Lynam, D. R., Caspi, A., Moffitt, T. E., Wikstrom, P. O., Loeber, R., Novak, S. P. (2000) The interaction between impulsivity and neighborhood context on offending: The effects of impulsivity are stronger in poorer neighborhoods. Journal of Abnormal Psychology. 109(4): 563-74.

${ }^{53}$ McLoyd \& Wilson, 1991.

${ }^{54}$ Hannon, L. (2005). Extremely poor neighborhoods and homicide. Social Science Quarterly, 86, 1418-1434.

${ }^{55}$ Bowen, N. K., \& Bowen, G. L. (1999). Effects of crime and violence in neighborhoods and schools on the school behavior and performance of adolescents. Journal of Adolescent Research, 14, 319-342

${ }^{56}$ Jones, D., Forehand, R., Brody, G., and Armistead, L. (2002). Psychosocial adjustment of African American children in single-mother families: a test of 3 risk models. Journal of Marriage and Family, 64(1), 105-115.

${ }^{57}$ McLeod \& Shanahan, 1993; Eamon, M. K. (2000). Structural model of the effects of poverty on externalizing and internalizing behaviors of four- to five-year-old children. Social Work Research, 24(3), 143-154. 
${ }^{58}$ Sampson, R. and Laub, J. (1994). Urban poverty and the family context of delinquency: a new look at structure and process in a classic study. Child Development, 65, 523-540.

${ }^{59}$ Corcoran, M. and Chaudry, A. (1997). The dynamics of childhood poverty. The Future

of Children, 7(2), 40-54; Vartanian, T. P. (1999). Adolescent neighborhood effects on labor market and economic outcomes. Social Service Review, 73(2), 142-167.

${ }^{60}$ Peters, H.E., \& Mullis, N.C. (1997). The role of family income and sources of income in adolescent achievement. In G. J. Duncan \& J. Brooks-Gunn (Eds.), Consequences of growing up poor (pp. 340-381). New York: Russell Sage Foundation; Hauser, R. M., \& Sweeney, M. M. (1997). Does poverty in adolescence affect the life chances of high school graduates? In G. J. Duncan \& J. Brooks-Gunn (Eds.), Consequences of growing up poor (pp. 541-595). New York: Russell Sage Foundation.

${ }^{61}$ Corocoran, M. (2001). pp. 133.

${ }^{62}$ Duncan, G. J., Ludwig, J., Magnuson, K.A., (2007). Reducing poverty through preschool interventions. The Future of Children (17) 2.

${ }^{63}$ Klerman, L. V. (1991). The health of poor children: Problems and programs. In A. Huston (Ed.), Children and poverty: Child development and public policy (pp. 136-157). New York: Cambridge University Press.

${ }^{64}$ Bronte-Tinkew, J., Zaslow, M., Capps, R., \& Horowitz, A. (2007). Food insecurity and overweight among infants and toddlers: New insights into a troubling linkage. Washington, DC: Child Trends.

${ }^{65}$ Klerman, L. K. (1991b). Alive and well? A review of health policies and programs for young children. New York: National Center for Children in Poverty.

${ }^{66}$ Korenman, S., \& Miller, J. E. (1997). Effects of long-term poverty on physical health of children in the National Longitudinal Survey of Youth. In G. Duncan \& J. Brooks-Gunn (Eds.), Consequences of growing up poor (pp. 70-99). New York: Russell Sage Foundation.

${ }^{67}$ Korenman \& Miller, 1997; Brooks-Gunn \& Duncan, 1997.

${ }^{68}$ Phipps, S.A., Burton, P.S., Osberg, L.S., \& Lethbridge, L.N. (2006). Poverty and the extent of child obestity in Canada, Norway and the United States. The International Association for the Study of Obesity: obesity reviews, 7, 5-12.

${ }^{69}$ Klerman, 1991.

${ }^{70}$ Alaimo, K., Olson, C. M., Frongillo, E. A., \& Briefel, R. R. (2001). Food insufficiency, family income, and health in U.S. preschool and school-aged children. American Journal of Public Health, 91(5), 781-786.

${ }^{71}$ Lowry, R., Kann, L., Collins, J. L., \& Kolbe, L. J. (1996). The effect of socioeconomic status on chronic disease risk behaviors among U.S. adolescents. Journal of the American Medical Association, 276(10), 792-797.

${ }^{72}$ Afxentiou, D., \& Hawley, C. B. (1997). Explaining female teenagers' sexual behavior and outcomes: A bivariate probit analysis with selectivity correction. Journal of Family and Economic Issues, 18(1), 91-106; Lammers, C., Ireland, M., Resnick, M., \& Blum, R. (2000). Influences on adolescents' decision to postpone onset of sexual intercourse: A survival analysis of virginity among youths ages 13 to 18 years.

Journal of Adolescent Health, 26(1), 42-48.

${ }^{73}$ Evans, G. W. (2003). A multimethodological analysis of cumulative risk and allostatic load among rural children. Developmental Psychology, 39, 924-933.

${ }^{74}$ Miller, J., \& Korenman, S. (1994). Poverty and children's nutritional status in the United States.

American Journal of Epidemiology, 140(3), 233-243.

${ }^{75}$ National Center for Children in Poverty. (1999). Poverty and brain development. Columbia University, Mailman School of Public Health. http://www.nccp.org/publications/pub_398.html.

${ }^{76}$ Mather, M., \& Adams, D. (2006). A KIDS COUNT/PRB Report on Census 2000: The Risk of Negative Child Outcomes in Low-Income Families. KIDS COUNT \& Population Reference Bureau. http://www.aecf.org/upload/PublicationFiles/DA3622H1234.pdf.

${ }^{77}$ Huffman, L.C., Mehlinger, S.L., \& Kerivan, A.S. (2000). Risk Factors for Academic and Behavioral Problems at the Beginning of School. The Child and Mental Health Foundation Agencies Network.

${ }^{78}$ Knitzer, J., Theberge, S., Johnson, K. (2008). Reducing maternal depression and its impact on young children: Toward a responsive early childhood policy framework. Columbia University, Mailman School of Public Health. http://www.nccp.org/publications/pdf/text_791.pdf.

${ }^{79}$ Institute of Medicine \& National Research Council of the National Academies. (2004). Children's health and the nation's wealth._Washington, DC: The National Academies Press.

${ }^{80}$ Garmezy, N. (1993). Children in poverty: Resilience despite risk. Psychiatry: Interpersonal and Biological Processes, 56(1), $127-136$.

${ }^{81}$ Kramer, R. (2000). Poverty, inequality, and youth violence. Annals of the American Academy of Political and Social Science, 567, 123-138.

${ }^{82}$ McLoyd, V.C., \& Wilson, L. (1991). The strain of living poor: Parenting, social support, and child mental health. In A. Huston (Ed.), Children and poverty: Child development and public policy (pp. 105-135). New York: Cambridge University Press; U.S. Department of Housing and Urban Development. (2000). Rental housing assistance-The worsening crisis. Washington, DC: U.S. Department of Housing and Urban Development.

${ }^{83}$ McLoyd, V. (1998). Socioeconomic disadvantage and child development. American Psychologist, 53(2), 185-204.

${ }^{84}$ Wilson, W. (1987). The truly disadvantaged: The inner city, the underclass, and public policy. Chicago, IL: University of Chicago Press.

${ }^{85}$ Klerman, 1991b.

${ }^{86}$ Child well-being refers to positive developmental outcomes regarding child health and safety, education and cognitive development, behavior, and psychological development; Moore, K.A., Lippman, L., \& Brown, B. (2004). Indicators of Child Well-Being: The Promise for Positive Youth Development. The Annals of the American Academy of Political and Social Science, 591,125-145.

${ }^{87}$ Annie E. Casey Foundation. (2002). Kids count data book: State profiles of child well-being. Baltimore, MD: Annie E. Casey Foundation. ${ }^{88}$ Mayer, S. (1997). What money can't buy: Family income and children's life chances. Cambridge: Harvard University Press.

${ }^{88}$ Zaslow, et al., 2002; Hasim, K., \& Moore, K.A. (2008) What works for increasing family income and parental employment:lessons from experimental evaluations of programs and interventions. Washington, DC: Child Trends. 
${ }^{90}$ Wertheimer, R. (2001, May). Working poor families with children: Leaving welfare doesn't necessarily mean leaving poverty (Research Brief). Washington, DC: Child Trends.

${ }^{91}$ Greenberg, M., Dutta-Gupta, I., \& Minoff, E. (2007). From Poverty to Prosperity: A National Strategy to Cut Poverty in Half. Washington, DC: Center for American Progress Task Force on Poverty.

${ }^{92}$ Wertheimer, R., Long, M., \& Jager, J. (2002). Children in working poor families: update and extensions. Washington, DC: Child Trends.

${ }^{93}$ Zaslow, M.J., Moore, K.A., Brooks, J.L., Morris, P.A., Tout, K., Redd, Z.A., \& Emig, C. (2002). Experimental studies of welfare reform and children. The Future of Children, 12(1), 79-96.

${ }^{94}$ Greenstein, R. (2005). The Earned Income Tax Credit: Boosting Employment, Aiding the Working Poor. Washington, DC: Center on Budget and Policy Priorities.

${ }^{95}$ Wertheimer, 2001; Ellwood, D., \& Sawhill, I. V. (2000). Fixing the marriage penalty in the EITC. Washington, DC: Brookings Institution; Carasso, A. \& Steuerle, C.E. (2005). The Hefty Penalty on Marriage Facing Many Households with Children. The Future of Children (pp. 157-175). Washington, DC: Brookings Institution Press.

${ }^{96}$ Capretta, J.C. (2008). Investing in Middle Class Families: The case for a much expanded child tax credit. Big Ideas for Children: Investing in out Nation's Future, (pp. 211-218). Washington, DC: First Focus.

${ }^{97}$ Sawhill, I. (1999, June). Nonmarital births and child poverty in the United States. Testimony before the House Committee on Ways and Means, Subcommittee on Human Resources, Washington, DC; Ball, V. \& Moore, K.A. (2007). What Works for Adolescent Reproductive Health: Lessons from Experimental Evaluations of Programs and Interventions. Washington, DC: Child Trends; Kane, A. \& Sawhill, I. (2003). Preventing Early Childbearing. In I. Sawhill (Ed.), One Percent for the Kids: New Policies, Brighter Futures for America's Children (pp. 56-75). Washington, DC: Brookings Institution Press; Dion, M.R. (2005). Healthy Marriage Programs: Learning What Works. The Future of Children (pp. 139-156). Washington, DC: Brookings Institution Press.

${ }^{98}$ Sorenson, E., \& Zibman, C. (2000). Child support offers some protection against poverty. Washington, DC: The Urban Institute.

${ }^{99}$ Sorenson \& Zibman, 2000.

${ }^{100}$ Sorenson \& Zibman, 2000.

${ }^{101}$ Meyer, D. R., Cancian, M., et al. (2001). W-2 Child support demonstration evaluation phase 1: Final report. Volume I: Effects of the experiment. Madison, WI: Institute for Research on Poverty, University of Wisconsin at Madison; Turetsky, V. (2005). In Everybody's Best Interests: Why Reforming Child Support Distribution Makes Sense for Government and Families. Washington, DC: Center for Law and Social Policy.

${ }^{102}$ Seltzer, J. A., McLanahan, S. S., \& Hanson, T. L. (1998). Will child support increase father-child contact and parental conflict after separation? In I. Garfinkel, S. McLanahan, D. Meyer, \& J. Seltzer (Eds.), Fathers under fire: The revolution in child support enforcement (pp. 157190). New York: Russell Sage Foundation.

${ }^{103}$ Sorenson, E., \& Zibman, C. (2001). Poor dads who don't pay child support: Deadbeat or disadvantaged? Washington, DC: The Urban Institute.

${ }^{104}$ Miller, C., \& Knox,V. (2001). The challenge of helping low-income fathers support their children: Final lessons from parents' fair share. Washington, DC: Manpower Demonstration Research Corporation.

${ }^{105}$ See findings of an evaluation of the STEP-UP mentoring program for young fathers at http://www.acf.dhhs.gov/programs/cse/rpt/fth/ fth b.htm.

${ }^{106}$ Wertheimer, R. (2003). Poor Families in 2001: Parents Working Less and Children Continue to Lag Behind. Washington, DC: Child Trends

${ }^{107}$ Alaimo, et al., 2001; Alaimo, K., Briefel, R. R., Frongillo, E. A., \& Olson, C. M. (1998). Food insufficiency exists in the United States: Results from the third National Health and Nutrition Examination Survey (NHANES III). American Journal of Public Health, 88 (3), $419-426$.

${ }^{108}$ National Research Council. (2002). Health insurance is a family matter. Washington, DC: National Academies Press. Retrieved from http://ferret.bls.census.gov/macro/032002/health/h08 000.htm

${ }^{109}$ Zedlewski, et al., 2002; Annie E. Casey Foundation, 2002; Lerman \& Wiseman, 2002.

\section{ACKNOWLEDGEMENTS}

The authors wish to thank Richard Wertheimer, Ph.D., for his helpful suggestions on this Research Brief. This research was funded by the Annie E. Casey Foundation. We thank them for their support, but acknowledge that the findings and conclusions presented in this report are those of the author(s) alone, and do not necessarily reflect the opinions of the Foundation.

Editor: Harriet J. Scarupa

Child Trends is a nonprofit, nonpartisan research center that studies children at all stages of development. Our mission is to improve outcomes for children by providing research, data, and analysis to the people and institutions whose decisions and actions affect children. For additional information on Child Trends, including publications available to download, visit our Web site at www.childtrends.org. For the latest information on more than 100 key indicators of child and youth well-being, visit the Child Trends DataBank at www.childtrendsdatabank.org. For summaries of over 330 experimental evaluations of social interventions for children, visit www.childtrends.org/LINKS.

(C) 2009 Child Trends 